\title{
Simultaneous phycoremediation of petrochemical wastewater and lipid production by Chlorella vulgaris
}

\author{
Rozita Madadi ${ }^{1} \cdot$ Mohammad Ali Zahed $^{2}$ (1) Ahmad Ali Pourbabaee ${ }^{3} \cdot$ Meisam Tabatabaei $^{4}$. \\ Mohammad Reza Naghavi ${ }^{5}$
}

Received: 29 October 2020 / Accepted: 17 March 2021 / Published online: 26 March 2021

(c) The Author(s) $2021 \quad$ OPEN

\begin{abstract}
A novel strategy of using microalgae Chlorella vulgaris for simultaneous bio-treatment of petrochemical wastewater and lipid production was developed in the present study. Phycoremediation was carried out in 30 days. The profile of fatty acids was identified, and the specifications of biodiesel including saponification value, iodine value, cetane number, long-chain saturated factor, cold filter plugging point, cloud point, allylic position equivalent and bis-allylic position equivalent were predicted by BiodieselAnalyzer ${ }^{\circledR}$ software. Besides, polycyclic aromatic hydrocarbons were determined in both wastewater samples and produced lipid. The observed data showed that biodiesel from C. vulgaris was superior to petrodiesel in terms of suitability in diesel engines. Moreover, contamination of petrochemical wastewater can influence the expression of a variety of genes in algae. To investigate the effectiveness of contamination on the expression of lipid synthesis as well as three photosynthesis genes, a real-time polymerase chain reaction assay was used to quantify transcript levels of $P s a B$ (photosystem I reaction center protein subunit B), $p s b C$ (an integral membrane protein component of photosystem II), and $r b c L$ (a large subunit of ribulose-1,5-bisphosphate carboxylase oxygenase). Furthermore, the gene expression level of $a c c D$ (acetyl-coenzyme A carboxylase carboxyl transferase subunit beta, chloroplastic) was studied to discover the effect of wastewater on lipid production. The results showed that when diluted petrochemical wastewater (50\%) was used as a media for $C$. vulgaris cultivation, these genes expression significantly increased. For $50 \%$ diluted wastewater, the maximum removal of BOD, COD, total nitrogen, and total phosphor has been $30.36 \%, 10.89 \%$, $69.89 \%$, and $92.59 \%$, respectively.
\end{abstract}

Keywords Phycoremediation · Petrochemical wastewater treatment · Biodiesel $\cdot$ Real-time PCR $\cdot$ Chlorella vulgaris

\section{Introduction}

Most of the industrial sectors cause severe negative impacts on the environment. Petrochemical industries are one of the major polluting industries [1]. In the phycoremediation method, algae are used to treat environmental contaminants [2]. Phycoremediation technology is economical, sustainable, energy-efficient, and highly proficient in removing pollutants from the water in comparison with the physical and chemical treatment

Supplementary Information The online version contains supplementary material available at https://doi.org/10.1007/s42452-021-04511w.

Mohammad Ali Zahed, Zahed51@yahoo.com | 'Department of Agricultural Biotechnology, University College of Agriculture and Natural Resources, University of Tehran, Karaj, Iran. ${ }^{2}$ Faculty of Biological Sciences, Kharazmi University, Tehran, Iran. ${ }^{3}$ Department of Soil Science, Faculty of Agricultural Engineering and Technology, University College of Agriculture and Natural Resources, University of Tehran, Karaj, Iran. ${ }^{4}$ Department of Microbial Biotechnology and Biosafety, Agricultural Biotechnology Research Institute of Iran (ABRII), AREEO, P.O. Box: 31535-1897, Karaj, Iran. ${ }^{5}$ Department of Agronomy and Plant Breeding, University College of Agriculture and Natural Resources, University of Tehran, Karaj, Iran. 
methods [3]. In microalgae treatment, wastewater's nutrients and organics are converted to algae, which had raised interest over the last decades due to the sustainable production of lipid and other high-value biomolecules [4]. Microalgae are a large group of phototrophic microorganisms that play a significant role in the biofuel production field for several reasons, such as the ability to mitigate $\mathrm{CO} 2$, reduce greenhouse gas emission, and not competing with the food supply $[5,6]$. Algae have low area requirements, tolerance to harsh conditions, and the ability to grow in almost all types of water $[7,8]$. More importantly, microalgae are proficient in removing nutrients from wastewater and simultaneously generate biomass for biofuel [9]. Biofuel produced by microalgae is known as a carbon-neutral energy resource, and its consumption could reduce up to $50 \%$ of $\mathrm{CO} 2$ emissions compared with traditional petrodiesel [10]. Although traditional techniques are still in use, algae cultivation, as a novel approach, has been recently developed to treat wastewater with a high concentration of nutrients that have been developed in recent years [11]. Chlorella vulgaris is applied for treating wastewater as it can eliminate nitrogen, phosphorus, BOD, and COD successfully with diverse retention times in the range of $10 \mathrm{~h}$ to 42 days [12-14]. Salgueiro and co-authors (2016) studied the capacity of $C$. vulgaris for eliminating the phosphorous and organic matters from wastewater [15]. They proposed that $C$. Vulgaris can be utilized as a right candidate for reducing phosphorus level and chemical oxygen demand by $99 \%$ and $71 \%$, respectively.

Biodiesel is composed of a combination of fatty acid alkyl esters [16]. Lipid content and the fatty acid profile are noticeable factors in algae cultivation [17]. Microalgae species contain proteins, pigments and vitamins, and lipids, which have applications in cosmeceuticals, nutraceuticals, fine chemicals, pharmaceutics, and biodiesel $[18,19]$. The fatty acid profile of algal extracts plays an essential role in predicting biodiesel's physicochemical properties [20, 21]. Biodiesel is highly potential to develop as one of the most important bioenergy for carbon capture and storage (BECCS) technologies.

Studying the expression of genes involved in the photosynthesis pathway and lipid production provides the opportunity to investigate algae grown in a wastewater environment at a molecular level [22]. The key genes involved in photosynthesis include the large subunit gene encoding the ribulose enzyme 1 and 5 bisphosphate-carboxylase/oxygenase and $p s a B$ and $p s b C$ genes [23]. The acetyl coenzyme $A$ carboxylase is a crucial enzyme in lipid synthesis [24]. Based on the gene expression of the $\operatorname{acc} D$ gene, the lipid accumulation in algae showed a significant correlation with this gene expression [25].

This study aimed to investigate the dual role of C. vulgaris for bioremediation of petrochemical wastewater and

lipid production as a feedstock for biodiesel and study the expression of the main genes involved in photosynthesis and lipid synthesis in the $C$. vulgaris cultivated in the petrochemical wastewater, including the large subunit of ribulose 1 and 5-bisphosphate carboxylase/oxygenase, $p s b C, p s a B$, and $a c c D$ genes. The quality of produced lipid and biodiesel was also assessed in detail.

\section{Material and methods}

\subsection{Algal cultivation}

Microalgae C. vulgaris was purchased from the Scandinavian Culture Collection of Algae and Protozoa (CCAP). Following that, the microalgae was cultured in modified BG11 medium containing (g/L): $\mathrm{NaNO}_{3}(1.5) ; \mathrm{K}_{2} \mathrm{HPO}_{4}$ (0.04); $\mathrm{MgSO}_{4} \cdot 7 \mathrm{H}_{2} \mathrm{O}(0.075) ; \mathrm{CaCl}_{2}(0.036) ;$ citric acid (0.006); $\mathrm{Na}_{2} \mathrm{CO}_{3}(0.02) ; \mathrm{Na}_{2}$ EDTA (0.001); and ferric ammonium citrate $(0.006)$.

Wastewater samples were obtained from a petrochemical complex in Asaluyeh, Iran [26]. The composition of petrochemical wastewater is shown in Table 1. Four diluted wastewater levels of $25 \%, 50 \%, 75 \%$, and $100 \%$ were tested to explore the optimum concentration of wastewater and the nutrient removal efficiency for $C$. vulgaris. Two different wastewater levels $(50 \%, 100 \%)$ were used to investigate the genes' expression (the large subunit of ribulose 1 and 5-bisphosphate carboxylase/oxygenase, $p s b C$, psaB, and $a c c D$ genes) in the $C$. vulgaris cultivated in the wastewater.

The experiments were carried out at room temperature in $250 \mathrm{ml}$ Erlenmeyer flasks, each bioreactor containing $200 \mathrm{ml}$ of BG11 and wastewater samples, for daily cycles of $16 \mathrm{~h}$ light and $8 \mathrm{~h}$ dark [12]. The algae were grown for 30 days in triplicate Erlenmeyer flasks.

Table 1 The specification wastewater samples

\begin{tabular}{lll}
\hline No & Parameter & $\mathrm{mg} / \mathrm{L}$ \\
\hline 1 & $\mathrm{pH}$ & $5.5-8.0$ \\
2 & $\mathrm{TN}$ & $4.4-18$ \\
3 & $\mathrm{TP}$ & $2.5-3.7$ \\
4 & $\mathrm{TPH}$ & $50-150$ \\
5 & $\mathrm{COD}$ & $600-2300$ \\
6 & $\mathrm{BOD}$ & $200-1500$ \\
7 & $\mathrm{COD} / \mathrm{BOD}$ & $1.62-3.43$ \\
8 & $\mathrm{pb}$ & $0.25-1.29$ \\
9 & $\mathrm{Cd}$ & $0.33-0.91$ \\
10 & $\mathrm{Ni}$ & $0.42-1.15$ \\
11 & $\mathrm{Zn}$ & $0.6-2.77$ \\
12 & $\mathrm{Fe}$ & $3.11-11.16$ \\
13 & Total PAH & $2.2-8.6 \mu \mathrm{g} . \mathrm{L}$ \\
\hline
\end{tabular}




\subsection{Biomass production and lipid extraction}

At the end of the experiments, algal biomass was harvested by centrifugation at $3500 \mathrm{rpm}$ for $15 \mathrm{~min}$, and in order to determine dry weight biomass, the samples were lyophilized at $-60^{\circ} \mathrm{C}$ to reach a constant weight $\left(\mathrm{g} \mathrm{L}^{-1}\right.$ day $\left.{ }^{-1}\right)$. The method of Bligh and Dyer [27] was used for the extraction of total lipids. The lipid of algae was extracted by transferring the sample into a glass tube, and then methanol: chloroform 2:1 was added to that and mixed for $30 \mathrm{~min}$. This process was followed by shaking and spinning. After that, the lower layer separated and dried under nitrogen flow, and the total lipid concentration was determined gravimetrically [27].

\subsection{Chemical analysis}

Chemical oxygen demand (COD), total nitrogen (TN), and total phosphorus (TP) were measured by a Hach DR 5000 Spectrophotometer (Hach Company, Loveland, CO, USA). QA/QC was carried out according to the analysis procedure. Moreover, five-day biochemical oxygen demand (BOD) was determined following the standard method [28]. The free fatty acid profile was analyzed using a Gas Chromatograph coupled with Flame lonization Detector (GC-FID) (Agilent 6890; Agilent Technologies, Palo Alto, CA, USA). Polycyclic aromatic hydrocarbons (PAHs) were determined in both wastewater samples and the produced fatty acid. According to US-EPA (2018), samples were extracted by $n$-hexane. Determination of 16 US-EPA priority pollutant PAHs was performed by an Agilent 6890 gas chromatograph equipped with an Agilent 5970 mass selective detector. Besides, 48,953-U SUPELCO PAH Mix QA/QC was monitored as described by US-EPA procedures [26].

\subsection{Characteristics of biofuel}

Fatty acid content and composition were analyzed according to Breuer et al. [29]. As a gas carrier, helium was used at a constant flow rate of $1.1 \mathrm{~mL} / \mathrm{min}$. The temperature was programmed as follows: the initial temperature was held at $140^{\circ} \mathrm{C}$ for $1 \mathrm{~min}, 4^{\circ} \mathrm{C}$ per min ramp to $250^{\circ} \mathrm{C}$, and was held for $5 \mathrm{~min}$. The temperature of the detector and the injection port was kept at $260^{\circ} \mathrm{C}$. Then, $1-\mu \mathrm{L}$ of the sample was injected in spitless mode. SUPLCO standard of $18,919 / 18$ was used to identify fatty acids.

BiodieselAnalyzer software (version 2.2, BRTeam, KarajIran) was employed to determine biodiesel characteristics empirically [25]. The software predicted some characteristics of biodiesel such as saturated fatty acids (SFA), mono unsaturated fatty acid (MUFA), polyunsaturated fatty acid (PUFA), degree of unsaturation (DU), saponification value (SV), iodine value (IV), cetane number (CN) for control
(BG11 medium), \%50 diluted wastewater and pure wastewater media.

\subsection{Statistical analysis}

Statistical analyses were performed using SPSS 17.0 (SPSS, Chicago, IL, USA). In order to determine the statistical significance, a one-way analysis of variance (ANOVA) was used. When $P$ was less than 0.05 or 0.01 , the effects were significantly different. The Student's t-test was used for statistical significance between control and mean values of treated groups. Additionally, Duncan's Multiple Range tests were used to analyze the differences in relative expression levels of target genes.

\subsection{Gene expression analysis}

According to the manufacturer's instructions, total RNA was extracted from algae cells using TRIzol (Riboex GenAll, South Korea) and alcoholic deposition. Then, extracted RNA was verified by $1 \%$ agarose gel and measured via NanoDrop spectrophotometry (Thermo Scientific 2000c, USA) at 260, 280, and $230 \mathrm{~nm}$. Afterward, extracted RNA was treated utilizing DNase I (Thermo Scientific, USA) to remove contamination of genomic DNA. Meanwhile, single-strand CDNA was synthesized by reverse transcriptase (Fast CDNA kit, Takara Japan) using $1 \mu \mathrm{g}$ of total RNA. Herein, the oligo dT was performed as a primer to the synthesis of CDNA.

In this study, $a c c D, p s a B, p s b C, r b c L$ were selected as target genes, and 18S rRNA (X13688) was selected as a housekeeping gene [30]. Sequences of these genes were collected from NCBI and aligned by Bioedit software [31]. The Oligo 7 software and Primer-BLAST tool were also utilized to design and check target primers. Primers designed for real-time PCR and annealing temperature are shown in Table 2.

Real-time PCR was carried out using the Stepone system (ABI stepone Real-Time PCR, USA), with the fluorescent dye SYBR ${ }^{\circ}$ Green (Takara SYBR Green Kit). The real-time PCR was run at $95^{\circ} \mathrm{C}(10 \mathrm{~min}), 40 \mathrm{cycles}$ at $94^{\circ} \mathrm{C}(30 \mathrm{~s}), 58^{\circ} \mathrm{C}(30 \mathrm{~s})$, and $72{ }^{\circ} \mathrm{C}(20 \mathrm{~s})$. Afterward, obtained data was analyzed using Livak and Schmittgen's [32] method ( $\left.2^{-\Delta \Delta C t}\right)$ and normalized by multiplication efficiency. The mean comparison between different groups was tested based on the LSD test $(P<0.05)$.

To evaluate the CDNA quality, PCR was performed by primers of a housekeeping gene and query genes. Primers were designed based on exon-exon junction to avoid amplification of genomic DNA. According to Fig. 1, all of the studied genes illustrated the specificity of amplicons. Moreover, the melting curve analysis showed that all the primers are specific (Fig. 1, supplementary). 
Table 2 Primers designed for real-time PCR and annealing temperature

\begin{tabular}{|c|c|c|c|c|}
\hline Gene & Primer & Sequence & Sequence length & $\mathrm{Ta}$ \\
\hline \multirow[t]{2}{*}{ Accd } & Acc-F & $\begin{array}{l}\text { TTTAACTCGTACTACTCG } \\
\text { TGTGC }\end{array}$ & 123 & 56 \\
\hline & Acc- $R$ & $\begin{array}{l}\text { GGTGCCATTCCATCATCA } \\
\text { AAGG }\end{array}$ & & 57 \\
\hline \multirow[t]{2}{*}{$\mathrm{Rbcl}$} & $\mathrm{Rbc}-\mathrm{F}$ & $\begin{array}{l}\text { GCTACAGCAGAAGCA } \\
\text { ATGATG }\end{array}$ & 125 & 55 \\
\hline & $\mathrm{Rbc}-\mathrm{R}$ & $\begin{array}{l}\text { TCACGACAATAATGAGAT } \\
\text { AAACTTG }\end{array}$ & & 53 \\
\hline \multirow[t]{2}{*}{ PsaB } & PsB-F & $\begin{array}{l}\text { TTTCATCCTCAAACGCAA } \\
\text { AGTCTATGG }\end{array}$ & 129 & 60 \\
\hline & PsB-R & $\begin{array}{l}\text { TTCTCGCATACTGTGACC } \\
\text { AATACCG }\end{array}$ & & 61 \\
\hline \multirow[t]{2}{*}{ Psbc } & PsC-F & $\begin{array}{l}\text { GATGGATGGATTGTCAGC } \\
\text { GTAGATAAC }\end{array}$ & 177 & 60 \\
\hline & PsC-R & $\begin{array}{l}\text { AATGGCACCTAAACTGTA } \\
\text { AGAAAGATAAGC }\end{array}$ & & 61 \\
\hline \multirow[t]{2}{*}{$18 \mathrm{~S}$ rRNA } & 18S rRNA - F & $\begin{array}{l}\text { GGAGTATGGTCGCAAGGC } \\
\text { TGAAAC }\end{array}$ & 133 & 61 \\
\hline & $18 \mathrm{~S}$ rRNA -R & $\begin{array}{l}\text { CTCAATCTGTCAATCCTC } \\
\text { ACTATGTCTGG }\end{array}$ & & 61 \\
\hline
\end{tabular}
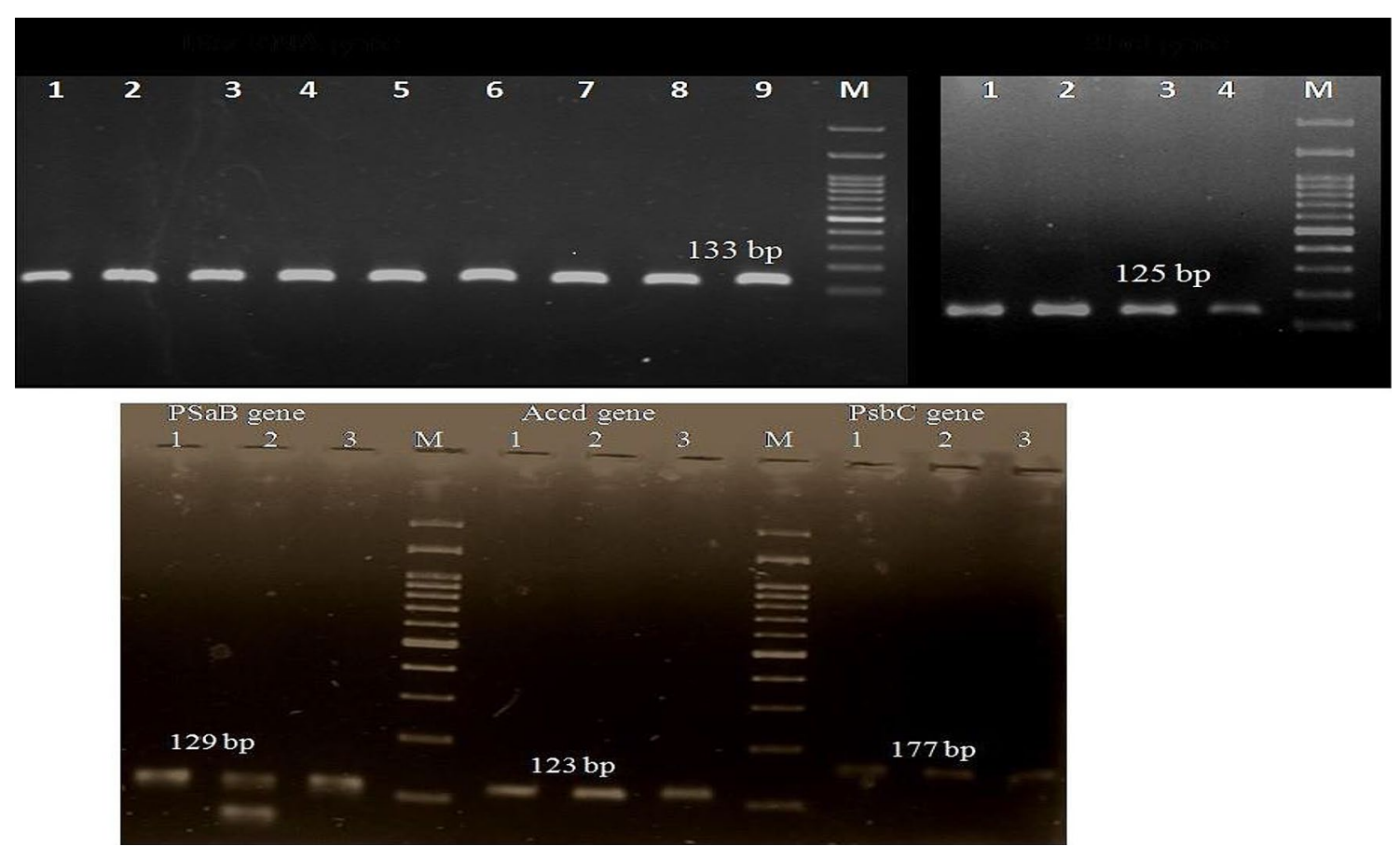

Fig. 1 PCR gel electrophoresis of cDNA synthetic on 1\% agarose gel. Lane M: DNA ladder, a rbcL gene, b $18 \mathrm{~S}$ rRNA. c $p s a B, a c c D, p s b C$ genes. Lane M: DNA ladder 


\section{Results and discussion}

\subsection{Phycoremediation}

The ability of $C$. vulgaris for simultaneous growth in wastewater streams as well as total nitrogen and total phosphor removal has been assessed. The highest percentage of total phosphorus removal was observed at $25 \%$ wastewater. The best performance of $C$. vulgaris for BOD removal was observed at $50 \%$ diluted wastewater. The highest percentage of COD removal was detected at $75 \%$ diluted wastewater, as presented in Tables 3, 4. According to the results of the t-test, all the variables examined (except BOD at $75 \%$ concentration) had statistically significant differences at $99 \%$ and $95 \%$ confidence intervals level with control. The results of the Student's t-test and the initial concentration of pollutants can be found in the supplementary data.

Cai and co-authors [33] found out a total nitrogen removal efficiency of $79-100 \%$ by microalgae S. obliquus from municipal wastewater. Lim et al. [34] attempted to treat textile wastewater samples using $C$. vulgaris and removed $\mathrm{N}$ and $\mathrm{P}$ by $45 \%$ and $33 \%$, respectively. $\mathrm{A}$ wide range of $\mathrm{N}(55-88 \%)$ and $\mathrm{P}(12-100 \%)$ removal was reported in the use of municipal wastewater as the waste stream [35-38].

\subsection{Lipid and biomass production}

C. vulgaris has been widely applied in the lipid production process employed in producing biofuels in the last decade. Since the media utilized in this research is free and available media, this is a practical approach.

The algal lipid composition was analyzed by GC-MS chromatography to determine PAHs in algal oil. Since PAHs were not detectable in all the samples, the lipid was used as a raw material for biodiesel production without any health and environmental concerns. ANOVA indicated no significant differences between biomass productions in BG11 and various diluted wastewater levels to evaluate the effect of diluted wastewater on biomass and lipid production. Biomass production was in the range of 0.402-0.470 g/L.D. For comparison matters, Duncan's
Table 4 Removal efficiency of the pollutants by Chlorella vulgaris (\%) in the petrochemical wastewater

\begin{tabular}{llrrr}
\hline Wastewater (\%) & \multicolumn{4}{l}{ Removal\% } \\
\cline { 2 - 5 } & TN & \multicolumn{1}{l}{ TP } & COD & BOD \\
\hline 25 & 59.14 & 100.00 & 12.11 & 20.63 \\
50 & 69.89 & 92.59 & 10.89 & 30.56 \\
75 & 63.80 & 93.83 & 12.17 & 14.02 \\
100 & 37.67 & 66.67 & 10.41 & 21.63 \\
\hline
\end{tabular}

multiple range test was also used. The comparison of the mean of the lipid content and biomass production in $C$. vulgaris by Duncan's method has been shown in Table 5 . According to the results, the highest lipid content was observed in $50 \%$ of wastewater. Then it was decreased by $75 \%$ and $100 \%$ of wastewater.

Zhou et al. [39] reported that Chlorella sp. produced biomass and lipid from municipal wastewater in the range of 231.40-241.70 $\mathrm{mgL}^{-1} \mathrm{~d}^{-1}$ and 30.91-33.53 DW\%. Chinnasamy et al. [40] achieved $23.00 \mathrm{mgL}^{-1} \mathrm{~d}^{-1}$ biomass and 18.10 DW\% lipids by Chlorella saccharophila from industrial wastewater. Ammonia nitrogen inhibited microalgae growth and reduced the utilization of wastewaters [41, 42]. The primary mechanism of ammonia was to inhibit the microalgae by poisoning their photosynthetic system $[43,44]$. The higher algal lipid content for $50 \%$ diluted petrochemical wastewater conditions resulted from the existence of $\mathrm{NH} 4+-\mathrm{N}$ in pure wastewater or having lower toxicity than $75 \%$ and pure wastewater.

The lipid accumulation using C. vulgaris is essential due to reduced expenses while producing a lipid that is a useful source to be utilized in biodiesel production. This approach is economically significant and may be developed as an applicable BECCS. The same approach has been recently suggested by Rosli and co-authors [45].

\subsection{Characteristics of biodiesel}

The results of chromatography showed that since the fatty acid profile generated by $C$. vulgaris contained a significant amount of palmitic acid (C16:0), stearic acid (C18:0), and palmitoleic acid (C16:1), oleic acid (C18:1), it could be used as promising biodiesel feedstock. The biodiesel's predicted
Table 3 Removal nutrients and organic contaminants by Chlorella vulgaris $(\mathrm{mg} / \mathrm{L})$

\begin{tabular}{lllcl}
\hline Wastewater (\%) & \multicolumn{3}{l}{ Removal $(\mathrm{mg} / \mathrm{L})$} & \\
\cline { 2 - 5 } & $\mathrm{TN}(\mathrm{mg} / \mathrm{L})$ & $\mathrm{TP}(\mathrm{mg} / \mathrm{L})$ & $\mathrm{COD}(\mathrm{mg} / \mathrm{L})$ & $\mathrm{BOD}(\mathrm{mg} / \mathrm{L})$ \\
\hline 25 & $1.25 \pm 0.02$ & $0.891 \pm 0.02$ & $450.43 \pm 0.14$ & $146.17 \pm 0.12$ \\
50 & $1.85 \pm 0.42$ & $0.132 \pm 0.33$ & $913.37 \pm 0.26$ & $116.88 \pm 0.53$ \\
75 & $3.34 \pm 0.53$ & $0.165 \pm 0.46$ & $1350.39 \pm 0.62$ & $217.1 \pm 0.45$ \\
100 & $7.67 \pm 0.01$ & $1.2 \pm 0.26$ & $1836.595 \pm 0.03$ & $287.39 \pm 0.56$ \\
\hline
\end{tabular}




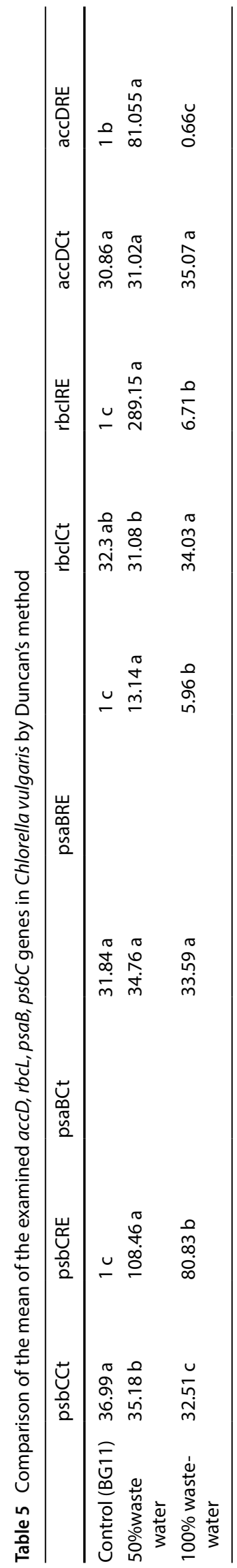

properties from C. vulgaris showed that they reached the standards developed by ASTM (Table 6). C. vulgaris was introduced as a suitable candidate for biodiesel production [46, 47]. Ji et al. [48] used a piggery wastewater sample (TN: $56 \pm 2 \mathrm{mg} / \mathrm{L}$ and TP: $13.5 \pm 0.6 \mathrm{mg} / \mathrm{L}$ ) as a medium for cultivation of $C$. vulgaris to integrate biofuel production and the treatment of piggery wastewater. They reported that C. vulgaris had good potential for treating wastewater as well as producing high oil content for lipid accumulation.

\subsection{Quality control of produced biodiesel}

PAHs were recognized as a mutagenic, carcinogenic, and teratogenic class of organic compounds, which was available in most of the wastewaters in the petroleum-related industries. Since the medium of algae was petrochemical wastewater in this study, PAH concentrations were determined in the produced lipid using gas chromatography/ mass spectroscopy. Each time, 16 US-EPA priority pollutant $\mathrm{PAH} s$ were measured. The results indicated that the biodiesel had outstanding quality, and PAHs were not detectable in all biodiesel samples. Presumably, C. vulgaris used carbon to accumulate lipids mainly by the source of $\mathrm{CO}_{2}$. Therefore, this type of produced biodiesel can be strongly proposed with no environmental concerns.

\subsection{Gene expression}

Since lipid composition and starch content vary among microalgae, not all are suitable for biofuel production. Some species can naturally biosynthesize and accumulate large amounts of starch and intracellular lipids, even further improved by genetic modifications, making them more useful in producing biofuels [49]. Statistical analysis of Duncan (Table 7) showed a significant difference in the relative expression of the $a c c D$ gene in $50 \%$ and $100 \%$ wastewater treatments compared to the control group. Treatment with $50 \%$ of wastewater had the highest expression, as can be seen in Fig. 2a. The expression of $r b c L$ and $p s b C$ also showed a significant difference between treatments, with high transcript abundance in $50 \%$ of effluent treatment (Fig. 2b, c). Based on the $\mathrm{Ct}$ value, this difference always exists. Likewise, the expression rate of $p s a B$ gene also illustrated the highest expression in $50 \%$ of wastewater compared to other treatments (Fig. 2d), while the $\mathrm{Ct}$ value showed no consistent difference as observed in the $r b c L$ gene. According to the results of Sect. 3.2, increasing the expression of genes involved in the photosynthesis pathway at $50 \%$ wastewater leads to the lipid content increased at this concentration. Increasing the expression of genes involved in the lipid synthesis pathway is well analyzed by the data obtained from the optimization and the corresponding 
Table 6 Predicted properties of biodiesel from Chlorella vulgaris by BiodieselAnalyzer ${ }^{\otimes}$ software

\begin{tabular}{|c|c|c|c|}
\hline & BG 11 & Wastewater (50\%) & Wastewater (100\%) \\
\hline Saturated fatty acids (SFA) & 32.4 & 29.0 & 26.6 \\
\hline Mono unsaturated fatty acid (MUFA) & 14.1 & 16.2 & 16.3 \\
\hline Poly unsaturated fatty acid (PUFA) & 20.5 & 22.1 & 26.8 \\
\hline Degree of unsaturation (DU) & 55.1 & 60.3 & 69.9 \\
\hline Saponification value (SV) & 135.796 & 136.755 & 141.500 \\
\hline lodine value (IV) & 77.036 & 77.897 & 92.134 \\
\hline Cetane number $(\mathrm{CN})$ & 69.160 & 68.684 & 64.143 \\
\hline Long chain saturated factor (LCSF) & 23.42 & 21.50 & 20.65 \\
\hline Cold filter plugging point (CFPP) ${ }^{\circ} \mathrm{C}$ & 57.02 & 51.07 & 48.39 \\
\hline Cloud point $(\mathrm{CP}){ }^{\circ} \mathrm{C}$ & -1.205 & -2.362 & -2.625 \\
\hline Allylic position equivalent (APE) & 41.0 & 44.1 & 54.4 \\
\hline Bis allylic position equivalents (BAPE) & 71.8 & 67.4 & 75.3 \\
\hline Oxidation stability (OS) (hours) & 11.525 & 10.263 & 8.547 \\
\hline Higher heating value (HHV) & 26.423 & 26.515 & 27.453 \\
\hline Kinematic viscosity $(\mathrm{U})\left(\mathrm{mm}^{2} \mathrm{~s}\right)$ & 2.415 & 2.410 & 2.437 \\
\hline Density $(\rho)\left(\mathrm{g} \mathrm{cm}^{3}\right)$ & 0.589 & 0.591 & 0.614 \\
\hline Pour point & -8.129 & -9.385 & -9.671 \\
\hline
\end{tabular}

mathematical models. According to the results of this study, nitrogen was found as a potential-limiting factor, which is confirmed by the statistical model. In addition, the affluent environment has no inhibitory effects on the expression of genes involved in the photosynthesis pathway as well as those involved in lipid synthesis.

Micro-algae stabilizes a considerable amount of carbon during photosynthesis; for example, the carbon fixation efficiency of $C$. vulgaris in the membrane photobioreactor is consistently $260 \mathrm{mg} / \mathrm{ha}$ [50]. Wawrik et al. showed that the expression of the ribulose 1 and 5 carboxylase/oxygenase ( $r b c L$ ) bisphosphate in species of diatoms living in the shallow-water is less pronounced than those living in deep water [51]. In addition, Wan et al. reported the expression of large enzyme 1 and 5 carboxylase/oxygenase bisphosphate in different species of microalgae (Dunaliella salina and Nannochloropsis oculata, sorokiniana, Chlorella) under mixed culture conditions [52]. In this study, they realized that the expression of $r b c L$ decreased in mixed culture conditions when glucose was added to the medium, which reduces the activity of $r b c L$ and, consequently, reduces the process of photosynthesis. Yan et al. studied the expression of $r b c L, p s a B$, and $p s b C$ genes involved in the photosynthesis process in Chlorella vulgaris species by adding glucose, atrazine, and diclofop-methyl herbicides, leading to decreased expression of $p s b C$ gene when these three herbicides are present, however, this expression was not significant. Nevertheless, the expression of $r b c L$ and $p s b C$ genes decreased significantly. Moreover, they found realtime PCR as a reliable technique for assessing the toxicity of components in aqueous media [53].
According to Fan et al. [54] the expression of the $r b c L$ gene in C. pyrenoidosa species in food deficiency conditions, including nitrogen, phosphorus, and iron, was inversely proportional to lipid content, proving the key role of this gene in photosynthesis and cell growth processes. However, the expression of the $\operatorname{acc} D$ gene had a negative correlation between the expression of this gene and lipid content. Lee et al. examined the effect of nitrogen deficiency on the transcript abundance of $a c c D$ gene and lipid content, and it was reported that the gene expression was directly related to lipid content [55].

\section{Conclusion}

Green algal Chlorella vulgaris was successfully employed for phycoremediation of petrochemical wastewater and lipid productivity at the same time. Biodiesel's physical and chemical characteristics demonstrate that biodiesel is a high-quality fuel and can easily adapt to diesel engines due to the sufficient similarities with petrodiesel, and it can be confidently recommended for diesel vehicles without a further engine change. PAHs were not detectable in all samples, which ensured the use of industrial wastewaters as an applicable source of alternative microalgae. The expression of $a c c D$ in the wastewater environment was 40 times higher than that in the BG11 medium. In addition, the expression of this gene in $50 \%$ of effluent was significantly increased compared to $100 \%$ effluent and the BG11 environments. For $100 \%$ non-diluted wastewater (pure wastewater), the maximum removal of $B O D, C O D$, total nitrogen, and total phosphor has been $21.63 \%, 10.41 \%$, 


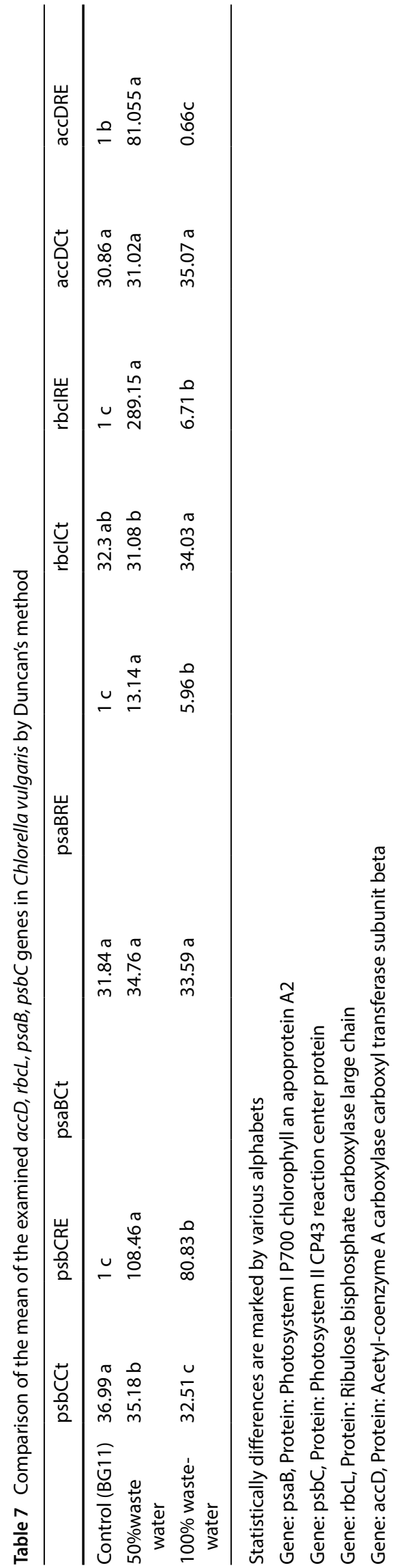

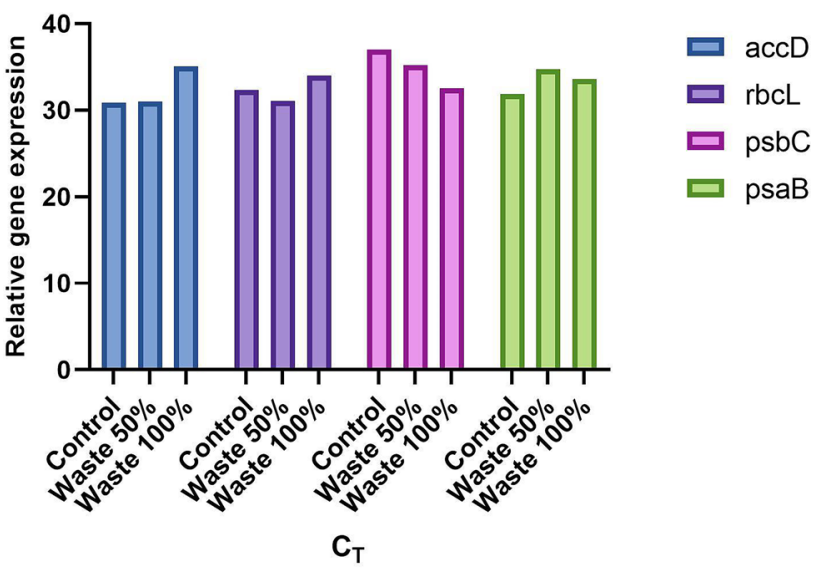

Fig. 2 Relative expression of $a c c D, r b c L, p s b C$, and $p s a B$ genes for various wastewater treatments

$37.67 \%$, and $66.67 \%$, respectively. Since many pollutants are emitted in the petrochemical wastewater, its application as a media for algae cultivation may change its function as a biomass production and lipid accumulation, as well as its potential for remediation, lipid composition, and expression of photosynthesis genes functions.

Future studies should be directed toward applications of $C$. vulgaris for the treatment of wastewater from other industries, including food, beverage, agriculture, aquaculture. The biodiesel and petrodiesel blend should be developed for diesel consumer engines, which are presumably useful in capturing $\mathrm{CO} 2$ from the atmosphere.

Acknowledgments The authors would like to appreciate Mr. Ali Ahmadzadeh from Pars Special Economic Energy Zone (PSEEZ) for his support in sampling on the field.

\section{Declarations}

Conflict of interest The authors have no conflicts of interest to declare that are relevant to the content of this article.

Open Access This article is licensed under a Creative Commons Attribution 4.0 International License, which permits use, sharing, adaptation, distribution and reproduction in any medium or format, as long as you give appropriate credit to the original author(s) and the source, provide a link to the Creative Commons licence, and indicate if changes were made. The images or other third party material in this article are included in the article's Creative Commons licence, unless indicated otherwise in a credit line to the material. If material is not included in the article's Creative Commons licence and your intended use is not permitted by statutory regulation or exceeds the permitted use, you will need to obtain permission directly from the copyright holder. To view a copy of this licence, visit http://creativecommons. org/licenses/by/4.0/. 


\section{References}

1. Prabakar D, Manimudi VT, Mathimani T, Kumar G, Rene ER, Pugazhendhi A et al (2018) Pretreatment technologies for industrial effluents: critical review on bioenergy production and environmental concerns. J Environ Manage 218:165-180

2. Sharma J, Kumar SS, Kumar V, Malyan SK, Mathimani T, Bishnoi NR, Pugazhendhi A (2020) Upgrading of microalgal consortia with $\mathrm{CO} 2$ from fermentation of wheat straw for the phycoremediation of domestic wastewater. Bioresour Technol 305:123063

3. Sharma J, Kumar V, Kumar SS, Malyan SK, Mathimani T, Bishnoi NR, Pugazhendhi A (2020) Microalgal consortia for municipal wastewater treatment-Lipid augmentation and fatty acid profiling for biodiesel production. J Photochem Photobiol B Biol 202:111638

4. Yadav G, Shanmugam S, Sivaramakrishnan R, Kumar D, Mathimani T, Brindhadevi K, Pugazhendhi A, Rajendran K (2021) Mechanism and challenges behind algae as a wastewater treatment choice for bioenergy production and beyond. Fuel 285:119093

5. Mathimani T, Baldinelli A, Rajendran K, Prabakar D, Matheswaran M, van Leeuwen RP, Pugazhendhi A (2019) Review on cultivation and thermochemical conversion of microalgae to fuels and chemicals: process evaluation and knowledge gaps. J Clean Prod 208:1053-1064

6. Gayglou SE, Tafakori V, Zahed MA, Khamoushi A (2021) Two promoters of biodiesel and biomass production induced by different concentrations of myo-inositol in Chlorella vulgaris. Biomass Convers Biorefinery pp 1-9

7. Anto S, Mukherjee SS, Muthappa R, Mathimani T, Deviram G, Kumar SS, Verma TN, Pugazhendhi A (2020) Algae as green energy reserve: Technological outlook on biofuel production. Chemosphere 242:125079

8. Sarker NK, Salam PA (2019) Indoor and outdoor cultivation of Chlorella vulgaris and its application in wastewater treatment in a tropical city-Bangkok, Thailand. SN Appl Sci 1:1-13

9. Mathimani T, Pugazhendhi A (2019) Utilization of algae for biofuel, bio-products and bio-remediation. Biocatal Agric Biotechnol 17:326-330

10. Nordin N, Yusof N, Maeda T, Mustapha NA, Yusoff MZM, Khairuddin RFR (2020) Mechanism of carbon partitioning towards starch and triacylglycerol in Chlorella vulgaris under nitrogen stress through whole-transcriptome analysis. Biomass Bioenerg 138:105600

11. Park JBK, Craggs RJ, Shilton AN (2011) Wastewater treatment high rate algal ponds for biofuel production. Bioresour Technol 102:35-42

12. Madadi R, Pourbabaee AA, Tabatabaei M, Zahed MA, Naghavi MR (2016) Treatment of petrochemical wastewater by the green algae Chlorella vulgaris. Int J Environ Res 10:555-560

13. Lois-Milevicich J, Casá N, Alvarez P, Mateucci R, Busto V, de Escalada PM (2020) Chlorella vulgaris biomass production using brewery wastewater with high chemical oxygen demand. J Appl Phycol 32:2773-2783

14. Azizi S, Bayat B, Tayebati H, Hashemi A, Pajoum Shariati F (2020) Nitrate and phosphate removal from treated wastewater by Chlorella vulgaris under various light regimes within membrane flat plate photobioreactor. Environ Prog Sustain Energy pe13519

15. Salgueiro JL, Perez L, Maceiras R, Sanchez A, Cancela A (2016) Bioremediation of wastewater using Chlorella vulgaris microalgae: Phosphorus and organic matter. Int J Environ Res 10:465-470

16. Demirbas A (2017) Tomorrow's biofuels: Goals and hopes. Energy Sources, Part A Recover Util Environ Eff 39:673-679
17. Mao G, Shi K, Zhang C, Li J, Chen S, Wang P (2020) Biodiesel Fuel from Chlorella vulgaris and Effects of Its Low-Level Blends on the Performance, Emissions, and Combustion Characteristics of a Nonroad Diesel Engine. J Energy Eng 146:4020016

18. López G, Yate C, Ramos FA, Cala MP, Restrepo S, Baena S (2019) Production of polyunsaturated fatty acids and lipids from autotrophic, mixotrophic and heterotrophic cultivation of Galdieria sp. strain USBA-GBX-832. Sci Rep 9:1-13

19. Hess SK, Lepetit B, Kroth PG, Mecking S (2018) Production of chemicals from microalgae lipids-status and perspectives. Eur J Lipid Sci Technol 120:1700152

20. Aguieiras ECG, de Barros DSN, Sousa H, Fernandez-Lafuente R, Freire DMG (2017) Influence of the raw material on the final properties of biodiesel produced using lipase from Rhizomucor miehei grown on babassu cake as biocatalyst of esterification reactions. Renew Energy 113:112-118

21. Madadi R, Tabatabaei M, Aghbashlo M, Zahed MA, Pourbabaee AA (2018) Biodiesel from microalgae. Waste to Wealth. Springer, Berlin, pp 277-318

22. Khamoushi A, Tafakori V, Zahed MA, Gayglou SE, Angaji SA (2020) Augmenting the expression of accD and rbcL genes using optimized iron concentration to achieve higher biomass and biodiesel in Chlorella vulgaris. Biotechnol Lett 42:2631-2641

23. Zhao F, Xiang Q, Zhou Y, Xu X, Qiu X, Yu Y, Ahmad F (2017) Evaluation of the toxicity of herbicide topramezone to Chlorella vulgaris: oxidative stress, cell morphology and photosynthetic activity. Ecotoxicol Environ Saf 143:129-135

24. Courchesne NMD, Parisien A, Wang B, Lan CQ (2009) Enhancement of lipid production using biochemical, genetic and transcription factor engineering approaches. J Biotechnol 141:31-41

25. Talebi AF, Tohidfar M, Bagheri A, Lyon SR, Salehi-Ashtiani K, Tabatabaei M (2014) Manipulation of carbon flux into fatty acid biosynthesis pathway in Dunaliella salina using AccD and ME genes to enhance lipid content and to improve produced biodiesel quality. Biofuel Res J 1:91-97

26. US-EPA, (2018) METHOD 8270E, SEMIVOLATILE ORGANIC COMPOUNDS BY GAS CHROMATOGRAPHY/MASS SPECTROMETRY, Revision 6. US Environmental Protection Agency, USA

27. Bligh EG, Dyer WJ (1959) A rapid method of total lipid extraction and purification. Can J Biochem Physiol 37:911-917

28. APHA (2017) Standard methods for the examination of water and wastewater, 23rd Edition

29. Breuer G, Evers WAC, de Vree JH, Kleinegris DMM, Martens DE, Wijffels RH, Lamers PP (2013) Analysis of fatty acid content and composition in microalgae. J Vis Exp. https://doi.org/10.3791/ 50628

30. Qian H, Sheng GD, Liu W, Lu Y, Liu Z, Fu Z (2008) Inhibitory effects of atrazine on Chlorella vulgaris as assessed by realtime polymerase chain reaction. Environ Toxicol Chem An Int J 27:182-187

31. Hall TA, et al (1999) BioEdit: a user-friendly biological sequence alignment editor and analysis program for Windows 95/98/NT. In: Nucleic acids symposium series. pp 95-98

32. Livak KJ, Schmittgen TD (2001) Analysis of relative gene expression data using real-time quantitative PCR and the 2- $\Delta \Delta C T$ method. Methods 25:402-408

33. Cai T, Park SY, Li Y (2013) Nutrient recovery from wastewater streams by microalgae: status and prospects. Renew Sustain Energy Rev 19:360-369

34. Lim S-L, Chu W-L, Phang S-M (2010) Use of Chlorella vulgaris for bioremediation of textile wastewater. Bioresour Technol 101:7314-7322

35. Khan M, Yoshida N (2008) Effect of L-glutamic acid on the growth and ammonium removal from ammonium solution 
and natural wastewater by Chlorella vulgaris NTM06. Bioresour Technol 99:575-582

36. Li Y, Zhou W, Hu B, Min M, Chen P, Ruan RR (2011) Integration of algae cultivation as biodiesel production feedstock with municipal wastewater treatment: strains screening and significance evaluation of environmental factors. Bioresour Technol 102:10861-10867

37. Ruiz-Marin A, Mendoza-Espinosa LG, Stephenson T (2010) Growth and nutrient removal in free and immobilized green algae in batch and semi-continuous cultures treating real wastewater. Bioresour Technol 101:58-64

38. Petrini S, Foladori P, Beghini F, Armanini F, Segata N, Andreottola $G$ (2020) How inoculation affects the development and the performances of microalgal-bacterial consortia treating real municipal wastewater. J Environ Manage 263:110427

39. Zhou W, Li Y, Min M, Hu B, Chen P, Ruan R (2011) Local bioprospecting for high-lipid producing microalgal strains to be grown on concentrated municipal wastewater for biofuel production. Bioresour Technol 102:6909-6919

40. Chinnasamy S, Bhatnagar A, Claxton R, Das KC (2010) Biomass and bioenergy production potential of microalgae consortium in open and closed bioreactors using untreated carpet industry effluent as growth medium. Bioresour Technol 101:6751-6760

41. Dai G-Z, Qiu B-S, Forchhammer K (2014) Ammonium tolerance in the cyanobacterium S ynechocystis sp. strain PCC 6803 and the role of the psbA multigene family. Plant Cell Environ 37:840-851

42. Peccia J, Haznedaroglu B, Gutierrez J, Zimmerman JB (2013) Nitrogen supply is an important driver of sustainable microalgae biofuel production. Trends Biotechnol 31:134-138

43. Yao L, Shi J, Miao X (2015) Mixed wastewater coupled with CO 2 for microalgae culturing and nutrient removal. PLoS ONE 10:e0139117

44. Li X, Li W, Zhai J, Wei H, Wang Q (2019) Effect of ammonium nitrogen on microalgal growth, biochemical composition and photosynthetic performance in mixotrophic cultivation. Bioresour Technol 273:368-376

45. Rosli SS, Kadir WNA, Wong CY, Han FY, Lim JW, Lam MK, Yusup S, Kiatkittipong W, Kiatkittipong K, Usman A (2020) Insight review of attached microalgae growth focusing on support material packed in photobioreactor for sustainable biodiesel production and wastewater bioremediation. Renew Sustain Energy Rev 134:110306
46. Al-lwayzy SH, Yusaf T, Al-Juboori RA (2014) Biofuels from the fresh water microalgae Chlorella vulgaris (FWM-CV) for diesel engines. Energies 7:1829-1851

47. Mallick N, Mandal S, Singh AK, Bishai M, Dash A (2012) Green microalga Chlorella vulgaris as a potential feedstock for biodiesel. J Chem Technol Biotechnol 87:137-145

48. Ji M-K, Kim H-C, Sapireddy VR, Yun H-S, Abou-Shanab RAl, Choi J, Lee W, Timmes TC, Jeon B-H et al (2013) Simultaneous nutrient removal and lipid production from pretreated piggery wastewater by Chlorella vulgaris YSW-04. Appl Microbiol Biotechnol 97:2701-2710

49. Khan S, Fu P (2020) Biotechnological perspectives on algae: a viable option for next generation biofuels. Curr Opin Biotechnol 62:146-152

50. Cheng L, Zhang L, Chen $\mathrm{H}$, Gao C (2006) Carbon dioxide removal from air by microalgae cultured in a membrane-photobioreactor. Sep Purif Technol 50:324-329

51. Wawrik B, Paul JH, Tabita FR (2002) Real-time PCR quantification of rbcL (ribulose-1, 5-bisphosphate carboxylase/oxygenase) mRNA in diatoms and pelagophytes. Appl Environ Microbiol 68:3771-3779

52. Wan M, Liu P, Xia J, Rosenberg JN, Oyler GA, Betenbaugh MJ, Nie Z, Qiu G (2011) The effect of mixotrophy on microalgal growth, lipid content, and expression levels of three pathway genes in Chlorella sorokiniana. Appl Microbiol Biotechnol 91:835-844

53. Yan D, Lu Y, Chen Y-F, Wu Q (2011) Waste molasses alone displaces glucose-based medium for microalgal fermentation towards cost-saving biodiesel production. Bioresour Technol 102:6487-6493

54. Fan J, Cui Y, Wan M, Wang W, Li Y (2014) Lipid accumulation and biosynthesis genes response of the oleaginous Chlorella pyrenoidosa under three nutrition stressors. Biotechnol Biofuels $7: 1-14$

55. Lee SK, Jee WSF, Funk DC, Jordan JS (2015) Analysis of attendees' expenditure patterns to recurring annual events: Examining the joint effects of repeat attendance and travel distance. Tour Manag 46:177-186

Publisher's Note Springer Nature remains neutral with regard to jurisdictional claims in published maps and institutional affiliations. 